\title{
Isolation of Rubella Virus from Abortion Material
}

\author{
K. M. THOMPSON, ${ }^{*}$ F.I.M.L.T. ; J. O'H. TOBIN, $†$ B.M., DIP.BACT., M.R.C.PATH.
}

British Medical fournal, 1970, 2, 264-266

\begin{abstract}
Cummary: Rubella virus was isolated from the fetus or $\$$ products of conception in 29 out of 32 cases $(91 \%)$ terminated because of clinical maternal rubella proved or supported by laboratory findings in the first trimester of pregnancy. Virus was isolated from similar material from only 3 out of $19(16 \%)$ other clinical cases of rubella in which the laboratory findings were inconclusive or against the diagnosis or in which no laboratory tests were done. Virus was found in the amniotic fluid if the fetus was infected and there was no evidence that the placenta was any real barrier to fetal infection.
\end{abstract}

\section{Introduction}

The isolation of rubella virus from the offspring of women infected during early pregnancy has been well documented. Virus has been found both in the embryo itself and in the placenta following abortion and may be excreted from the throat or the urine for months by infected infants or may persist for longer periods in the lens of the eye (Norrby, 1969). The incidence of intrauterine infection following abortion for maternal rubella has, however, varied from $40 \%$ (Heggie, 1967) to $91 \%$ (Rawls et al., 1968). During 1968 and 1969 we have examined the fetuses, placentas, or products of - conception both from women with rubella infection in which the diagnosis was confirmed or supported by the laboratory findings and from women suspected of having clinical rubella without laboratory confirmation of the disease. The results are given here.

\section{Materials and Methods}

The RK13 line of rabbit kidney cells (Beale et al., 1963) was used for virus isolation, and cultures were treated as previously described (Hutchinson and Thompson, 1965), except that the basal medium used consisted of $50 \% 199$ solution (Glaxo) and $50 \%$ Eagle's minimum essential medium (Burroughs Wellcome) containing $0.044 \%$ sodium bicarbonate and antibiotics. For cell growth and maintenance horse serum (Evans Medical) and extra sodium bicarbonate were added to the basal medium, the final concentrations being $5 \%$ and $0.088 \%$ for growth and $2.5 \%$ and $0.132 \%$ for maintenance. Basal medium only was used for the adsorption medium.

Material was received from 58 cases, of which 17 were from the Manchester area, 15 from Derby, 8 from Oxford, 7 from Grimsby, and 6 from Chester. Single specimens were received from five other areas.

Specimens were sent in bottles or plastic bags (which are not recommended unless being delivered by hand) by either road or post from women aborted from a few hours to a few days previously because of rubella infection. If a fetus was received in its amniotic sac this fluid was removed before selected organs, usually the lungs, liver, kidney, eye, and brain were dissected out. If the embryo had already been damaged by the operative procedure selected material was washed well in basal medium before processing. Unless absolute identification was possible material was designated as products of conception. Individual organs were either tested separately or pooled, depending on the number of cell cultures available. These pools usually consisted of brain and eye, heart and lung, liver and kidney.

\footnotetext{
* Chief Technician.

+ Director

Public Health Laboratory, Withington Hospital, Manchester M20 8LR.
}

Tissues were finely minced with scissors and suspended in about four times their volume in basal medium in 1-oz. (28$\mathrm{ml}$.) universal containers and shaken vigorously by hand before being spun in a refrigerated M.S.E. medium centrifuge at about 800 r.p.m. for five minutes. Three or four fivefold to tenfold dilutions of supernatant fluid from each sample or of amniotic fluid were then made and inoculated into RK13 cultures, usually using only one tube culture per dilution. The cultures were rolled for 24 to 48 hours at $35^{\circ} \mathrm{C}$, after which the adsorption medium was removed and maintenance medium used for the remainder of the time of incubation. The cells were examined twice weekly and the medium changed after this procedure. If the classical cytopathic effect was not seen in the primary cultures within two weeks, tubes from each dilution series were pooled, subcultured to two RK13 cell cultures, and incubated for another two weeks before being discarded.

When a classical cytopathic effect was observed this was allowed to progress until at least $50 \%$ of the cell sheet was affected, at which time the supernatant fluid was used in a neutralization test with a rabbit antiserum prepared from the West Point strain of rubella virus. A normal rabbit control serum and a virus control were included in the tests. When this identification test had been completed the virus control tube was subcultured into a rhesus monkey kidney culture and observed for any cytopathic effect, a haemadsorption test with guinea-pig cells being performed on it at the end of one week. This procedure was adopted because of our observation that some parainfluenza viruses, which can produce a clinical picture resembling rubella, can have a cytopathic effect in RK13 cells similar to that due to rubella virus and because of the risk of non-specific inhibition of the parainfluenza virus by rabbit serum. No viruses other than rubella were isolated from abortion material in RK13 cultures. Specimens were not inoculated into other types of cell cultures. Cervical swabs were placed in $2.5 \mathrm{ml}$. of transport medium for sending to the laboratory.

Neutralization and haemagglutination inhibition tests for rubella antibody in patients' sera were done by methods previously described (Hutchinson and Thompson, 1965; Field et al., 1967), except that the haemagglutination inhibition technique was varied by including bovine albumin in the 1day-old chick red cell suspension and mixing $0.6 \mathrm{ml}$. of dextrose, gelatin, and Veronal diluent to each $0.2 \mathrm{ml}$. of serum before adding $1.2 \mathrm{ml}$. of $25 \%$ kaolin, and in the neutralization test the media used were those described above.

\section{Results}

The number of rubella virus isolations in the different clinical and laboratory categories are given in the Table. Virus was isolated from the abortion material in 14 out of 16 of those clinical cases with rubella infection confirmed by rising antibody titre, in 15 out of 19 of those clinical cases with haemagglutination inhibition titres of over $1 / 320$ in serum samples taken 14 to 84 days after illness, from 1 out of 9 clinical cases with titres equal or less than $1 / 320$, and from 2 out of 10 cases diagniosed on clinical grounds alone.

Three of the four cases failing to yield virus in the group of 19 with haemagglutination inhibition titres greater than $1 / 320$ in convalescence had initial blood samples taken within 24 hours of the appearance of the rash. All three had the same high haemagglutination inhibition and neutralization titres $(\geqslant 1 / 32)$ in both initial and convalescent serum samples, indicating that the clinical disease producing the rash was not rubella. If these cases are excluded rubella virus was found in 
Isolation of Rubella Virus from Intrauterine Material by Clinical and Laboratory Categories.

\begin{tabular}{|c|c|c|c|c|c|c|}
\hline \multirow{2}{*}{ Category } & \multicolumn{5}{|c|}{ Number Yielding Virus/Number Tested } & \multirow{2}{*}{$\begin{array}{c}\% \\
\text { Cases } \\
\text { Yielding } \\
\text { Virus }\end{array}$} \\
\hline & Fetus & $\underset{\text { Fluid }}{\text { Amniotic }}$ & Placenta & $\begin{array}{l}\text { Products of } \\
\text { Conception }\end{array}$ & Total & \\
\hline $\begin{array}{l}\text { Rising titre } \\
\quad+\text { rash } \\
\begin{array}{l}\text { H.A.I. titre } \\
\text { + rash }\end{array}\end{array}$ & $\begin{array}{l}8 / 10 \\
7 / 9\end{array}$ & $\begin{array}{c}3 / 4 \\
-\end{array}$ & $\begin{array}{l}5 / 6 \\
3 / 5\end{array}$ & $\begin{array}{l}5 / 6 \\
8 / 10\end{array}$ & $\begin{array}{l}14 / 16 \\
15 / 19\end{array}$ & $\begin{array}{l}87 \cdot 5 \\
78 \cdot 8\end{array}$ \\
\hline $\begin{array}{l}\text { Total "proved" } \\
\text { clinical cases" }\end{array}$ & $15 / 17$ & $3 / 4$ & $8 / 10$ & $13 / 15$ & $29 / 32$ & $90 \cdot 6$ \\
\hline 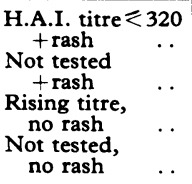 & $\begin{array}{l}1 / 3 \\
1 / 3 \\
1 / 2 \\
0 / 1\end{array}$ & $\begin{array}{l}- \\
1 / 1 \\
1 / 2 \\
0 / 1\end{array}$ & $\begin{array}{l}1 / 2 \\
0 / 2 \\
0 / 1\end{array}$ & $\begin{array}{l}0 / 6 \\
1 / 7 \\
- \\
0 / 1\end{array}$ & \begin{tabular}{l|}
$1 / 9$ \\
$2 / 10$ \\
$1 / 2$ \\
$0 / 2$
\end{tabular} & $\begin{array}{l}11 \cdot 1 \\
20 \cdot 0 \\
(50 \cdot 0) \\
(0)\end{array}$ \\
\hline
\end{tabular}

*Excluding cases shown not to be rubella by laboratory tests.

15 out of 17 fetuses, in 8 out of 10 placentas and in 13 out of 15 products of conception-an isolation rate of $91 \%$ from the intrauterine material of the 32 cases in which the clinical diagnosis was supported by the laboratory. The virus isolation rate was $16 \%$ in the 19 clinical cases not investigated or supported (haemagglutination inhibition titre equal or less than $1 / 320$ ) by the laboratory.

In one instance virus was found in the placenta but not in the fetus, and in another it was found in the fetus but not in the placenta. Virus was also found in the fetus but not in the placenta of one of two women with subclinical infection. In the three instances of failure to isolate virus from cases of rubella proved by the laboratory, one fetus was macerated on receipt, and in the others material had been in the post for three to four days. On the other hand, virus was found in very low titre in the kidney of one fetus in which material reached the laboratory three days after the pregnancy was terminated.

Specimens from 30 out of 33 cases yielding virus and from 20 out of 25 failing to do so reached the laboratory within 24 hours of the termination. In the positive virus group one specimen took 48 hours and another two 72 hours on the way, while in the negative group one took 48 hours, three 72 hours, and one five days. All the specimens from patients terminated on clinical grounds alone reached the laboratory within 24 hours.

When individual organs were tested separately virus was isolated from fetal eye (2/3), lung (4/5), brain (3/4), liver (4/5), and kidney $(4 / 4)$. When pools were tested the virus was found in eye and brain (3/5), lung and heart (4/5), and liver and kidney $(6 / 6)$. The titres in these organs ranged from a few infectious particles to over $1,000 / \mathrm{g}$. of tissue examined.

Virus was found in five out of six amniotic fluids cultured in those cases in which the fetus was obtained complete within the amniotic sac. In the fluids yielding virus the fetus was also infected. Rubella virus was found only in the placenta in the case in which virus was not isolated from the amniotic fluid.

Only 7 of the 33 women who yielded infected material had convalescent haemagglutination inhibition titres of less than $1 / 1,280$ - one had a titre of $1 / 320$, two a titre of $1 / 480$, and four a titre of $1 / 640$. Convalescent neutralization titres varied from $1 / 8$ to $1 / 64$, the level being generally proportional to the time lapsing between disease and the taking of the blood sample.

\section{Discussion}

The results obtained here would suggest that nearly all the fetuses of mothers contracting rubella in the first 12 weeks of pregnancy are infected with. rubella virus. For the fetus to escape infection is the exception. Our results therefore agree with the findings of Rawls et al. (1968) rather than with those of other workers (Alford et al., 1964; Horstmann et al., 1965;
Monif et al., 1965; Heggie, 1967), who found a smaller rate of virus isolation from fetal material. Rawls et al. found that growing out cell cultures from the embryos produced higher yields than that by the more usual method of grinding up material and inoculating supernatant fluids. Our methods of preparing cell suspensions are perhaps more gentle than the usual methods and explain the high isolation rate we obtained without growing out cell cultures from the embryo. We also used RK13 cells for isolation instead of vervet monkey kidney cells, a cell system apparently preferred by most American workers. None of our material was frozen at any time before processing and inoculation into cell cultures.

Amniotic fluid from infected embryos yielded virus, but whether amniocentesis would be a reliable method for diagnosing infected fetuses early enough in pregnancy to be useful will depend on future experience. The difference in the virus isolation rate from those fetuses whose mothers had proved clinical rubella in the first four weeks $(4 / 5)$, in the second four weeks $(16 / 16)$, or in the third four weeks of pregnancy $(9 / 11)$ was not pronounced. Cooper (1968) found a falling isolation rate relative to the time of gestation when rubella occurred.

There was no difference in the seasonal distribution of cases in which virus was or was not found: $80 \%$ of those yielding rubella-infected material and $79 \%$ of those not doing so had their rashes in the first or second trimesters of each year when rubella was most prevalent.

Our results would suggest that by our haemagglutination inhibition tests a titre of greater than $1 / 320$ in the convalescent serum of a woman with a history of a rubella-like illness supports a diagnosis of german measles, with a chance of being right in $75-80 \%$ of cases. The incidence of these titres by our tests in women without a recent history of rubella infection is $33 \%$-a figure complementary to that given above. An haemagglutination inhibition titre of less than $1 / 320$ would be against a diagnosis of rubella and one of $1 / 320$ would make the diagnosis unlikely. It must be stressed, however, that in any individual case these titres are only a guide to whether a rash a few weeks previous to the taking of a blood sample was likely to be rubella or not. Until more sophisticated methods of diagnosis are generally available (Best et al., 1969; Brown et al., 1969) the only definite serological diagnostic indication of infection will remain an adequate rising antibody titre. A rise may be more readily demonstrated, especially in those cases in which serum samples are not received immediately after th? clinical illness, if the haemagglutination inhibition test is combined with the neutralization and/or complement-fixation test. Rubella antibody titres estimated by the latter procedures tend to rise more slowly than those shown by the haemagglutination inhibition test.

Though infected embryos may not always result in infants with overt congenital defects, minor non-structural abnormalities, such as mental retardation, communication defects, etc., may well be missed if they are not followed up extremely carefully for a prolonged period. Hardy et al. (1969), in a long-term combined clinical and virological study, described the presence of such abnormalities in some infants whose mothers had been infected even after the first trimester, though most of these infants appeared to be normal during the neonatal period. It cannot be assumed that the placenta is a particularly good barrier against fetal spread or that virus isolated from the products of conception probably came from placental tissue only or the mother's cervix. Excretion from the latter source does not apparently persist for more than a short time after clinical illness, as virus was not found there in our seven positive cases tested and who were aborted from two to six weeks after illness.

The high rate of virus isolation from infected embryos as compared with that from newborns and mothers with rubella in pregnancy supports the suggestion that a proportion of infected fetuses "cure" themselves before delivery (Dudgeon, 1969). This would explain those cases with both clinical and 
laboratory evidence of maternal infection in which neither virus excretion nor persistence of antibody can be demonstrated in the infant though the congenital abnormalities are typical of congenital rubella.

It must be concluded that clinical rubella in the first trimester confirmed by the laboratory means an infected fetus. It also appears that termination of a pregnancy for suspected rubella without laboratory support for the diagnosis is destroying many fetuses unnecessarily.

Our thanks are due to those clinicians who sent us material from their cases; to Dr. B. W. Barton, Derby, Dr. A. M. R. Mackenzie, Oxford, Dr. H. S. Lawy, Grimsby, and Dr. Pauline M. Poole, Chester, who forwarded material collected in their areas; to Dr. E. R. Mitchell, Nottingham, who isolated virus from the fetus of a case diganosed by us and allowed us to include his findings in our results; and to Miss Wendy Bagguley and Miss Lesley Robinson for laboratory assistance:

This work was supported by a grant from the Department of Health and Social Security to the Public Health Laboratory Service for the study of rubella in pregnancy.
REFERENCES

Alford, C. A., jun., Neva, F. A., and Weller, T. H. (1964). New England fournal of Medicine, 271, 1275 .

Beale, A. J., Christofinis, G. C., and Furminger, I. G. S. (1963). Lancet, 2, 640 .

Best, Jennifer M., Banatvala J. E., and Watson, D. (1969). Lancet, 2, 65. Brown, G. C., Baublis, J. V., and O'Leary, Theresa (1969). In Proceedings of the 23 rd Symposium on Rubella Vaccines, London, 1968, edited by R. H. Regamey et al., p.95. Basel, Karger.

Cooper, L. Z. (1968). Birth Defects Original Article Series, 4, No. 7, p. 23 .

Dudgeon, J. A. (1969). American Fournal of Diseases of Children, 118, 35.

Field, Anne M., Vandervelde, Elise M., Thompson, K. M., and Hutchinson, D. N. (1967). Lancet, 2, 182.

Hardy, B., McCracken, G. H., Gilkeson, Mary R., and Sever, J. L. (1969). Fournal of the American Medical Association, 207, 2414.

Heggie, A. D. (1967). Fournal of Pediatrics, 71, 777.

Horstmann, D. M., et al. (1965). American fournal of Diseases of Children, 110, 408.

Hutchinson, D. N., and Thompson, K. M. (1965). Monthly Bulletin of the Ministry of Health and the Public Health Laboratory Service, 24, 385 .

Monif, G. R. G., Sever, J. L., Schiff, G. M., and Traub, Renee G. (1965). American fournal of Obstetrics and Gynecology, 91, 1143.

Norrby, E. C. J. (1969). In Polyma Virus by B. E. Eddy, p.115. Vienna,

Springer.
Rawls, W. E., Desmyter, J., and Melnick, J. L. (1968). fournal of the American Medical Association, 203, 627.

\title{
Chlordiazepoxide (Librium) and Tests of Thyroid Function
}

\author{
FREDERICK CLARK,* M.B., B.S., M.R.C.P. ; REGINALD HALL, $\dagger$ M.D., B.SC., M.R.C.P.
}

British Medical fournal, 1970, 2, 266-268

\begin{abstract}
ummary: The effect of chlordiazepoxide (Librium) on thyroid function was examined in 14 euthyroid patients who required the drug for psychiatric reasons and in six patients with clinically mild thyrotoxicosis. There was no significant difference in results from tests of thyroid iodide trapping (thyroid radioiodine uptake, thyroid clearance, and absolute iodine uptake) or of thyroid hormone release (protein-bound iodine, T3 resin uptake, and free thyroxine index) carried out before and during treatment with the drug over a four-week period. It is suggested that chlordiazepoxide need not be withdrawn before thyroid status and function are assessed in any patient taking the drug.
\end{abstract}

\section{Introduction}

The list of drugs known to affect laboratory tests of thyroid function becomes more formidable year by year (Hall, 1967), and the clinician must be alert to the possibility that his patient has taken such agents, otherwise diagnostic confusion or error may result and inappropriate or unnecessary therapy instituted. Furthermore, even if the offending drug is withdrawn, diagnosis may have to be delayed until the metabolic effects of the drug have ceased, often a period of some weeks.

Recently it was reported that treatment with chlordiazepoxide (Librium) causes alterations in certain tests of thyroid function, in particular a low thyroid radioiodine uptake, in patients with clinical thyrotoxicosis (Baron, 1967; Harvey, 1967). The results of these reports appear to have been widely accepted (Today's Drugs, 1967; Walton and Thompson, 1969), though earlier studies by Oberman et al. (1963) did not show any effect of chlordiazepoxide $(40-80 \mathrm{mg}$. daily for 7 to 30 days) on the level of protein-bound iodine (P.B.I.), red cell uptake of ${ }^{131}$ I-labelled triiodothyronine, or 24-hour thyroid ${ }^{131}$ I uptake. Animal studies, using comparatively huge doses of the drug, showed depression of thyroid radioiodine uptake and release (Caprino, 1963), which, it was suggested, might be due to interference with pituitary release of thyroid-stimulating

* Consultant Physician, Newcastle General Hospital; Lecturer in Clinical Medicine, University of Newcastle upon Tyne, Royal Victoria Infirmary, Newcastle upon Tyne, NE1 4LP.

† Consultant Physician, Royal Victoria Infimary; Senior Lecturer in Medicine, University of Newcastle upon Tyne, Royal Victoria Infirmary, Newcastle upon Tyne, NE1 4LP hormone (T.S.H.). Nevertheless, Boris et al. (1961) and Schindler et al. (1966) failed to find any evidence of impairment of T.S.H. release by chlordiazepoxide in animals.

Chlordiazepoxide is often prescribed for anxiety and emotional disorders, and it is not uncommon to find that patients who are in fact thyrotoxic have been given the drug on the mistaken and possibly hazardous assumption that their illness is of psychiatric origin (Ashford and Ross, 1968). Other patients with psychiatric symptoms are taking the drug when it is suggested that thyrotoxicosis could be a cause of their complaint. In both situations laboratory investigation may be necessary for confirmation of the diagnosis.

With this background it appeared important to examine the problem further and ascertain the effect, if any, of chlordiazepoxide on tests of thyroid function in euthyroid and thyrotoxic patients.

\section{Subjects and Methods}

Euthyroid Group.-Fourteen patients ( 2 men and 12 women) aged 23 to 57, most of whom were referred from a group general practice, were tested before and after four weeks of continuing therapy with chlordiazepoxide in a dosage of 10 mg. three times a day. The patients, none of whom showed clinical evidence of thyroid disease, were selected on psychiatric grounds and were asked if they would take part in the trial. Those who agreed had their initial assessment within the next 48 hours, so there was little delay in starting treatment.

Thyrotoxic Group.-Six patients (all women) aged 37 to 55 with clinically apparent but relatively mild thyrotoxicosis (Graves' disease) were investigated. After standard initial diagnostic studies the patients were asked if they were prepared to defer definitive antithyroid therapy for a four-week period in order to determine any effect of chlordiazepoxide (10 mg. three times a day) on their symptoms and tests of thyroid function. All agreed, and after this time interval the tests were repeated. Subsequently, treatment with carbimazole was started.

Thyroid Function Tests.-Two measurements of thyroid function were assessed-thyroid iodide trapping and thyroid hormone release. In addition, the patients' sera were tested for the presence of thyroid autoantibodies by standard tanned red cell agglutination and complement fixation tests (W.H.O. 1966). 